MenNA, M. E. DI (1958). J. gen. Microbiol. 19, 581-583

\title{
Torulopsis ingeniosa n.sp., from Grass Leaves
}

\author{
BY MARGARET E. DI MENNA \\ Soil Bureau, Department of Scientific and Industrial Research, Wellington, \\ New Zealand
}

SUMMARY: An undescribed species of Torulopsis has been isolated from pasture grass leaves. It does not ferment sugars and assimilates glucose, sucrose, maltose, lactose, galactose and potassium nitrate. It is distinguished from Torulopsis aeria by the oval shape of its cells, mucoid cultures on solid media, and the ability to liquefy gelatin rapidly. It is proposed to name it $T$. ingeniosa.

Isolations of yeasts from the leaf surfaces of pasture plants (Lolium perenne, Trifolium repens and others) collected in various parts of New Zealand included a species which resembled Torulopsis aeria (Saito) Lodder in many respects. Cultures on solid media were yellowish cream in colour, there was no production of ascospores, ballistospores or pseudomycelium, and budding was on a narrow base. Sugars were not fermented, no starch was synthesized on the medium of Mager \& Aschner (1947), and glucose, sucrose, maltose, lactose, galactose and potassium nitrate were assimilated. However, as the cells were oval rather than 'almost round' (see Fig. 1), and as the texture of cultures on solid media was soft to mucoid or fluid and not 'dull glistening, almost smooth' (Lodder \& Kreger-van Rij, 1952, p. 413), some doubt was felt as to the taxon's identity with $T$. aeria.

Comparison of a strain from grass with the type culture of Torulopsis aeria from the Centraalbureau voor Schimmelcultures showed that they were two separate species. As the undescribed species was able to use a number of complex substrates as sole carbon sources and was proteolytic, amylolytic and pectinolytic, it is proposed to name it $T$. ingeniosa.

\section{Torulopsis ingeniosa n.sp.}

Cellulae in culturis novis ovoidae $(2 \cdot 5-3 \cdot 5) \times(4 \cdot 0-7 \cdot 5) \mu$. Cultura nova in agaro Sabouraudi albida, mollis saepe fluida. Pseudomycelium nullum. Fermentatio nulla. In medio minerali cum glucoso, saccharo, maltoso, lactoso, galactoso crescit. Nitras kalicus assimilatur. In cultura (post unum mensem) cellulae magniores sint. Cellulae circumdata capsula mucosa angusta.

Cells from young cultures oval (2.5-3.5) $\times(4 \cdot 0-7 \cdot 5) \mu$. Growth on Sabouraud (glucose peptone) agar cream coloured to yellowish, soft to mucoid, sometimes fluid. No pseudomycelium is formed. Giant cells may occur in old cultures. A narrow capsule is demonstrable.

Fermentation: absent.

Sugar assimilation: Glucose + Lactose +(sometimes weak)

$$
\begin{aligned}
& \text { Sucrose + Galactose +(sometimes weak) } \\
& \text { Maltose + }
\end{aligned}
$$

Assimilation of potassium nitrate: positive.

Biochemical tests were carried out by the methods of Lodder \& Kreger-van Rij (1952). 
Although cell shape and consistency of cultures on solid media were sufficient to show that Torulopsis ingeniosa was a different species from $T$. aeria, it seems advisable to include some supplementary character to distinguish the two taxa. Both the type strain of $T$. aeria and that of $T$. ingeniosa gave very weak growth with ethyl alcohol as a carbon source, and both species could split soluble starch and grow in a defined medium free from growth factors.

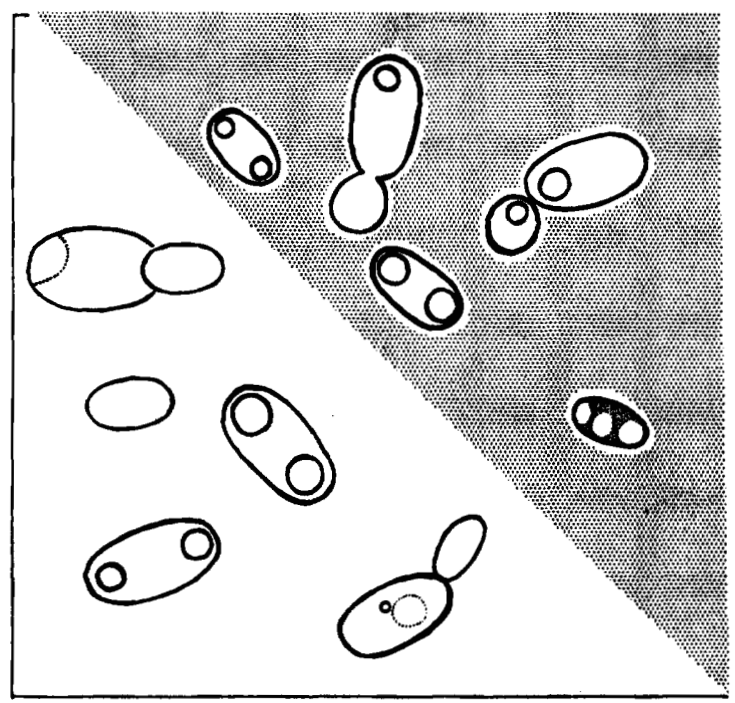

Fig. 1. Cells of Torulopsis ingeniosa showing narrow capsules. $\times 2500$.

When ferulic acid, vanillin and $p$-hydroxybenzaldehyde in $0.01 \%$ concentration $(w / v)$ were used as carbon sources, $T$. ingeniosa could assimilate all three, but $\boldsymbol{T}$. aeria could use only ferulic acid. However, these aromatic compounds are not used routinely in the laboratory and growth in them is slow. All strains of $T$. ingenios $a$ tested caused stratiform liquefaction of gelatin within a week; the type strain of $T$. aeria had not liquefied gelatin after incubation for 3 weeks. It is therefore suggested that liquefaction of gelatin be used as a supplementary test for $T$. ingeniosa.

Theoretically there appears to be some danger of confusing Torulopsis ingeniosa with those strains of Candida muscorum di Menna which produce limited amounts of pseudomycelium. Biochemically the two species are very similar (di Menna, 1958 and to be published), and both produce creamy mucoid to fluid cultures on solid media. In practice, production of pseudomycelium in $C$. muscorum and lack of any such growth form in T. ingeniosa have always been sufficiently marked to prevent confusion. A more important distinguishing feature between the two species seems to be habitat. $T$. ingeniosa has been isolated from leaves of pasture grasses and, less frequently and in smaller proportions, from the soil beneath the grasses. $C$. muscorum has been found in rotted sphagnum in peat bogs and in forest soils.

The type culture of Torulopsis ingeniosa, TG 27, isolated in July 1957 from 
grass leaves near Hamilton, New Zealand, has been deposited at the Centraalbureau voor Schimmelcultures, Yeast Division, Delft, Netherlands, and at the Brewing Industry Research Foundation, Nutfield, Surrey, England.

This paper is Soil Bureau Publication, no. 140.

\section{REFERENCES}

Lodder, J. \& Kreger-van RiJ, N. J. W. (1952). The Yeasts. A Taxonomic Study, p. 713. Amsterdam: North Holland Publishing Co.

MAgER, J. \& AschNer, M. (1947). Biological studies on capsulated yeasts. J. Bact. 53, 283.

Menna, M. E. DI (1958). Two new species of yeasts from New Zealand. J. gen. Microbiol. 18, 269.

(Received 13 June 1958) 